\title{
PROSPEK PENGEMBANGAN USAHA IKAN KERAPU SUNU (Plektropomus leopardus) PADA KARAMBA JARING APUNG BERBASIS AGRIBISNIS
}

\section{Prospect of Developing Business of Coral Trout Grouper (Plektropomus leopardus) Fish Farming with Floating Net Cage on Agribusiness Basis}

\author{
Seffyan Hendratno ${ }^{1)}$, Azhar Bafadal $^{2)}$, Budiyanto $^{2)}$ \\ ${ }^{1)}$ Program Studi Magister Agribisnis Universitas Halu Oleo \\ ${ }^{2)}$ Dosen Agribisnis Fakultas Pertanian Universitas Halu Oleo \\ email: hendrasinapoi@yahoo.com
}

\begin{abstract}
ABSTRAK
Penelitian ini dilaksanakan pada bulan Agustus 2015 sampai Desember 2016 di Perairan Kecamatan Tanggetada Kabupaten Kolaka. Penelitian ini bertujuan menganalisis prospek usaha budidaya kerapu sunu dengan sistem KJA dan menganalisis strategi pengembangan usaha budidaya ikan kerapu sunu dengan sistem KJA di Kecamatan Tanggetada Kabupaten Kolaka di masa yang akan datang. Metode penelitian ini menggunakan metode sensus dan data yang digunakan dalam penelitian dilakukan secara deskriptif (aspek teknis, aspek managerial, aspek pasar) dan kuantitatif dilakukan untuk menganalisis data finansial $(R / C$ Ratio). Jenis data yang digunakan data primer dan data sekunder. Hasil penelitian dari beberapa kondisi aspek teknis, aspek managerial, dan aspek pasar layak untuk dikembangkan dan hasil perhitungan Revenue Cost Ratio diperoleh nilai sebesar 3,79, dimana usaha budidaya ikan kerapu sunu di Kecamatan Tanggetada Kabupaten Kolaka layak dibudidayakan karena melihat penerimaan yang cukup tinggi. Hasil analisis SWOT berada pada strategi difersifikasi dimana usaha budidaya ikan kerapu sunu di Kecamatan Tanggetada walaupun menghadapi tantangan berat namun perlu meningkatkan kualitas dan kuantitas produk untuk menjamin keberlajutan dari usaha budidaya kerapu sunu di Kecamatan Tanggetada.
\end{abstract}

Kata Kunci: Faktor Internal, Faktor Eksternal, Prospektif, Budidaya Kerapu Sunu, KJA.

\begin{abstract}
This study was conducted from August 2015 to December 2016 in the water of Tanggetada sub regency of Kolaka. The study aimed to analyze the business prospect of farming coral trout grouper using KJA system and to analyze strategies for developing the business offarming coral trout grouper using KJA systemin Tanggetada sub regency of Kolaka in the future. The study used a census method. Data used in the study were analyzed descriptively (technical aspect, managerial aspect, market aspect) and quantitatively to analyze financial data $(R / C$ Ratio $)$. Types of data used were primary data and secondary data. Results of the study revealed that, in terms of technical, managerial, and market aspects, the business of farming coral trout grouper is physically feasible for development. Result of calculating Revenue Cost Ratiowas 3,79 indicating that the farming of coral trout grouper in Tanggetada sub district of Kolaka is feasible due to relatively high incomes gained in the business. Result of SWOT analysis of the farming of coral trout grouper showed that the business adopts adiversification strategy, in which the business of trout grouper farming at Tanggetada sub district faces a number of big challenges, but the quality and quantity of the products need to be improved in order to guarantee the sustainability of coral trout grouper farming business in the sub district of Tanggetada.
\end{abstract}

Keywords: internal factors, external factors, prospective, coral trout grouper farming, KJA 


\section{PENDAHULUAN}

Ikan kerapu hasil budidaya memiliki keunggulan dibandingkan dengan hasil tangkapan langsung di laut. Keunggulan yang pertama adalah ukuran ikan yang seragam, yang memungkinkan pembudidaya untuk memanen ikan pada saat ukuran panen/konsumsi yang memiliki nilai ekonomis paling tinggi yaitu pada saat ikan berbobot delapan ons dan mempunyai daging yang lezat, bergizi tinggi dan mengandung asam lemak tak jenuh. Yang kedua adalah pasokan ikan kerapu hasil budidaya dapat terus menerus ada karena dapat diatur masa penanaman dan panen sesuai dengan kebutuhan pembudidaya/pasar.

Salah satu wilayah Provinsi di Indonesia yang mempunyai kontribusi dalam produksi kerapu adalah Provinsi Sulawesi Tenggara yang memiliki sejumlah kawasan yang potensial bagi pengembangan budidaya ikan kerapu karena tipe perairan laut berupa teluk, selat, dan pulau-pulau kecil. Luas perairan laut Sulawesi Tenggara tercatat $110.000 \mathrm{~km}^{2}$ dengan luas wilayah kewenangan pegelolaan laut $79.700 \mathrm{~km}^{2}$. Dari luas kewenangan tersebut mencakup wilayah perairan di sekitar jazirah bagian Tenggara pulau Sulawesi, dua pulau besar (Pulau Buton dan Pulau Muna), 48 pulau berukuran sedang, tiga gagasan kepulauan (Wakatobi, Tiworo, dan Padamarang), serta 100 buah pulau kecil yang pada umumnya belum berpenghuni (Bappeda Sultra dalam La Sara, 2005).

Kabupaten Kolaka berada di wilayah Teluk Bone yang memiliki banyak potensi dibidang kelautan dan perikanan, antara lain ikan konsumsi, ikan hias, terumbu karang, rumput laut, dan mangrove. Ikan kerapu merupakan komoditas yang mempunyai nilai ekonomi tinggi dan prospek pengembangannya cukup baik. Budidaya ikan Kerapu Sunu (Plectropomus leopardus) di Kabupaten Kolaka luas Potensi $\pm 50 \mathrm{Ha}$, sementara yang baru dikembangkan sekitar 4,75 Ha, dengan produksi 2,93 ton/tahun (DKP, 2012).
Pengembangan komoditas ikan kerapu yang ada di Kabupaten Kolaka terdapat di tiga kecamatan yaitu Kecamatan Wundulako dengan menggunakan metode budidaya keramba jaring apung yang berada di Pulau Lambasina, Kecamatan Pomalaa dan Kecamatan Tanggetada. Komoditas yang dikembangkan adalah Kerapu Sunu (Plectropomus leopardus), Kerapu Bebek (Cromileptes altivelis), Kerapu Macan (Ephinephelus fuscoguttatus), Kerapu Lumpur (Epinephelus coloides).

Usaha KJA ikan kerapu sunu di Kecamatan Tanggetada merupakan bidang usaha yang baru (kurang dari sepuluh tahun) dikenal oleh masyarakat melalui pengusaha menengah. Walaupun produk dari usaha ini memiliki nilai jual yang cukup tinggi namun dalam operasionalnya memerlukan biaya yang cukup besar dan waktu panen yakni antara enam sampai delapan bulan. Kecamatan Tanggetada dengan luas Potensi perikanan $\pm 15 \mathrm{Ha}$, sementara yang baru dikembangkan sekitar 1,25 Ha yang dikelola oleh masyarakat nelayan sebanyak $15 \mathrm{KK}$ dengan produksi sekitar $\pm 1.500 \mathrm{~kg} /$ tahun. Kecamatan tanggetada memiliki pantai perairan yang sangat mendukung untuk pengembangan usaha perikanan terutama usaha budidaya ikan dan memiliki prospek yang sangat bagus untuk budidaya ikan kerapu dengan menggunakan karamba jaring apung (KJA).

Berdasarkan uraian pada pendahuluan potensi sumberdaya perairan di Kecamatan Tanggetada sangat penting terutama dalam pengembangan usaha budidaya ikan Kerapu Sunu maka beberapa permasalahan yang perlu dikaji yaitu:

1. Bagaimana prospek usaha budidaya kerapu sunu dengan sistem KJA sehingga dapat diketahui budidaya diatas layak atau tidak yang diusahakan oleh nelayan budidaya di Kecamatan Tanggetada?

2. Bagaimana strategi pengembangan usaha budidaya ikan Kerapu Sunu dengan sistem KJA di Kecamatan Tanggetada? 


\section{METODE PENELITIAN}

Penelitian ini dilaksanakan di lokasi budidaya Kerapu Sunu di Kecamatan Tanggetada Kabupaten Kolaka Provinsi Sulawesi Tenggara. Waktu penelitian mulai dilaksanakan pada bulan Agustus 2015 sampai Desember 2016. Jumlah populasi pembudidaya kerapu sunu sebanyak $15 \mathrm{KK}$ dan penentuan responden dalam penelitian ini menggunakan metode sensus.

Jenis pengumpulan data dalam penelitian ini terdiri dua kategori yaitu data primer dan data sekunder. Data primer diperoleh melalui wawancara langsung dengan menggunakan daftar kuisioner yang telah disiapkan sebelumnya. Sedangkan data sekunder diperoleh melalui sumber lain yang ada relevansinya dengan penelitian seperti Dinas Kelautan dan Perikanan Kabupaten Kolaka, kantor BPS Kabupaten Kolaka, Kantor Camat, Kantor Lurah/Desa dan observasi lapangan.

\section{Teknik Analisis Data}

Analisis data yang digunakan dalam penelitian ini dilakukan secara deskriptif dan kuantitatif. Analisis deskriptif digunakan untuk menganalisis data dari aspek teknis, aspek managerial, dan aspek pasar sedangkan analisis kuantitatif dilakukan untuk menganalisis aspek finansial.

\section{Analisis Kelayakan}

\section{Aspek Teknis}

Analisis aspek teknis dilakukan secara deskriptif. Hal-hal yang perlu diperhatikan dalam aspek teknis usaha budidaya ikan kerapu sunu terdiri dari lokasi usaha, luas produksi, tata letak (lay out), penyusunan peralatan usaha, proses produksi, dan teknologi atau mesin-mesin yang digunakan.

\section{Aspek Managerial}

Komponen dalam aspek managerial dan administratif dalam usaha budidaya ikan kerapu sunu terdiri atas struktur organisasi, spesifikasi tenaga kerja, wewenang dan tanggung jawab, dan pelaksana kegiatan usaha.

\section{Aspek Pasar}

Aspek pasar dianalisis secara deskriptif atau kualitatif. Analisis aspek pasar dilakukan untuk mengetahui potensi permintaan dan penawaran, harga dan strategi pemsaran perkiraan penjualan ikan, struktur pasar dan persaingan. Usaha pengembangan ikan kerapu dengan sistem KJA dikatakan layak ditinjau dari aspek pasar bila terdapat suatu permintaan dengan harga yang menguntungkan.

\section{Aspek Finansial}

Analisis finansial merupakan kajian keuangan untuk mengetahui keberhasilan dan penerimaan yang telah dicapai selama usaha ikan kerapu sunu tersebut berlangsung.

Keterangan:

$$
R / C \text { Ratio }=\frac{T R}{T C}
$$

$\mathrm{R} / \mathrm{C}$ Ratio $=$ Revenue Cost Ratio.

$\mathrm{TR}=$ Total Revenue (penerimaan kotor budidaya ikan kerapu).

$\mathrm{TC}=$ Total Cost (jumlah keseluruhan biaya yang harus dikeluarkan oleh pembudidaya ikan kerapu sebagai konsekuensi penggunaan input produksi).

\section{Analisis SWOT}

Untuk menganalisis strategi pengembangan usaha budidaya ikan Kerapu Sunu akan digunakan analisis SWOT. Adapun faktor eksternal dan internal yang akan dikaji dalam analisis SWOT adalah sebagai berikut :

1. Faktor eksternal adalah faktor-faktor yang berasal dari luar usaha budidaya yaitu :

a. Peluang terdiri dari : Harga, dukungan pemerintah, pasar, dan kemajuan teknologi.

b. Ancaman terdiri dari : Keamanan, adanya produk subtitusi dan penyakit. 
2. Faktor internal adalah faktor-faktor yang berasal dari dalam usaha budidaya ikan kerapu sunu yaitu :

a. Kekuatan terdiri dari : Letak lokasi budidaya, pemasaran, dan potensi SDM.

b. Kelemahan terdiri dari : Manajemen yang kurang baik, pengetahuan yang rendah, keterbatasan modal, dan ketersediaan bibit.

Alat yang dipakai untuk menyusun faktor-faktor strategis perusahaan adalah matrik SWOT. Matrik ini dapat menggambarkan secara jelas bagaimana peluang dan ancaman eksternal yang dihadapi perusahaan dapat disesuaikan dengan kekuatan dan kelemahan yang dimilikinya. Matrik ini dapat menghasilkan 4 set kemungkinan alternatif strategis (Rangkuti, 2003)

\section{HASIL DAN PEMBAHASAN Analisis Kelayakan Usaha Aspek Teknis}

1. Pemilihan Lokasi

Pemilihan lokasi yang ada di Kecamatan Tanggetada memenuhi beberapa kriteria atau syarat yang dipenuhi untuk dilaksanakannya budidaya ikan kerapu sunu dengan menggunakan KJA yaitu :

a. Periran yang terlindung dari angin dan gelombang besar.

b. Kedalaman perairan $\pm 15 \mathrm{~m}$ sesuai dengan budidaya sistem KJA.

c. Dasar perairan yang berkarang dan berpasir yang merupakan habitat alami dari ikan kerapu sunu.

d. Letak lokasi yang tidak mengganggu jalur pelayaran kapal.

e. Relatif dengan sumber pakan alami (ikan rucah).

f. Sarana transportasi yang tersedia.

g. Bebas dari bahan pencemar seperti limbah rumah tangga dan limbah tambang. h. Kecepatan arus 0,15-0,40 m/detik, kecerahan 6 meter, salinitas $32 \%$. DO 7,03 mg/I, dan $\mathrm{pH} 8,21$.

2. Luas Produksi

Produksi yang dimaksud yakni penambahan bobot kerapu yang dihasilkan oleh pembudidaya kerapu dalam satu kali siklus panen. Dengan demikian luas produksi berukuran 3,5 x 3,5 meter dalam satu unit karamba dengan rata-rata kotak/jaring 2-4 per unit dengan jumlah produksi budidaya kerapu di daerah penelitian rata-rata menghasilkan dalam satu kali panen sebanyak 85,33 kg/unit.

3. Tata Letak (Lay Out) KJA

Konstruksi karamba jaring apung terdiri dari kerangka jaring, pelampung, kantong atau jaring pemeliharaan ikan dan jangkar.

a. Kerangka jaring apung menggunakan kayu atau balok yang memiliki umur ekonomis selama tiga tahun. Jumlah kayu yang digunakan rata-rata sebanyak 34 batang per satu unit KJA.

b. Pelampung berfungsi untuk mengapungkan kerangka karamba jaring apung. Bahan pelampung yang akan digunakan adalah drum plastik dengan volume 200 liter yaitu rata-rata sebanyak 24 buah.

c. Kantong atau jaring digunakan untuk wadah pemeliharaan ikan. Bahan jaring yang digunakan biasanya terbuat dari net nylon atau polyethylene dengan ukuran mata jaring $1,27 \mathrm{~cm}$.

d. Pemberat jaring digunakan sebagai pemberat tiap sudut jaring yang ada didasar perairan agar jaring tidak terlipat atau naik kepermukaan dan terbuat dari bahan timah, batu, atau beton dengan berat rata-rata $5-8 \mathrm{~kg}$.

e. Tali jangkar digunakan agar seluruh sarana budidaya tidak bergeser dari tempatnya akibat pengaruh arus angin maupun gelombang. Bahan yang digunakan tali nylon sepanjang $\pm 18 \mathrm{~m}$ 
untuk mengikat jangkar dan jangkar terbuat dari besi.

4. Proses produksi atau kegiatan budidaya

a. Persiapan Wadah Pemeliharaan

Dalam satu unit KJA di lokasi penelitian terdiri dari 2-4 kotak/jaring sebagai wadah pemeliharaan/pembesaran ikan. Ukuran jaring yang digunakan adalah $3.5 \times 3.5 \mathrm{x}$ 3.5 meter per kotak.

b. Penebaran Bibit

Bibit yang ditebar rata-rata berukuran $\quad 8-10 \mathrm{~cm}$. Jumlah bibit yang ditebar rata-rata dalam satu unit adalah 173 ekor sehingga kepadatan ikan sesuai dengan standar padat tebar ikan yang disarankan.

c. Pemilihan dan Pemberian Pakan

Pemilihan pakan ikan kerapu yang berasal dari ikan rucah seperti ikan tembang, rebon, selar dan sejenisnya, selain harganya murah dan mudah diperoleh, juga karena pakan buatan khusus ikan kerapu memang belum ada di pasaran. Pemberian pakan untuk ikan kerapu sunu di lokasi budidaya yaitu dengan dosis pakan ikan rucah dalam satu hari sebanyak $\pm 2 \mathrm{~kg}$ dalam satu hari. Harga pakan rata-rata Rp 10.000$15.000 / \mathrm{kg}$ dipasar atau didapatkan dari hasil mencari sendiri.

d. Pengendalian Hama dan Penyakit

Hama yang dapat mengganggu produksi ikan kerapu di lokasi budidaya kerapu terutama burung-burung pemangsa ikan. Untuk mencegah jenis hama ini, dapat dilakukan dengan cara menutup permukaan karamba dengan daun kelapa, sehingga burung tidak dapat langsung masuk karamba. Hama lain yang mengganggu adalah ikan buntal atau ikan besar. Pencegahannya, harus diadakan pengontrolan secara rutin, termasuk pada malam hari.

Penyakit yang sering ada pada organisme ini adalah penyakit bintik- bintik putih kecil. Untuk menangani penyakit ini pembudidaya biasanya menggunakan air tawar untuk mengobati setiap organisme yang terkena penyakit bintik-bintik putih dengan cara merendamkan ikan kedalam media baskom atau ember dengan waktu $\pm 3-5$ menit.

e. Penyortiran

Penyortiran ikan bertujuan untuk mengetahui pertumbuhan, menentukan dosis pakan, dan memisahkan ikan yang berukuran sama kedalam satu kotak sehingga tidak ada sifat ikan kerapu yang kanibal.

f. Perbaikan dan Pembersihan Jaring

Perbaikan dan pembersihan jaring selama masa pemeliharaan selalu dilakukan oleh pembudidaya dengan jumlah tenaga kerja produktif sebanyak 2-3 orang. Jaring kotor akibat penempelan lumpur atau biota penempel, seperti kerang, teritip, dan alga. Pembersihan dan perbaikan jaring dilakukan 2 minggu sekali sampai ikan berumur tiga bulan dan setelah umur tiga bulan sampai masa panen perbaikan dan pembersihan dilakukan dua bulan sekali.

g. Panen dan Penangan Pasca Panen

Ada beberapa hal yang perlu diperhatikan untuk menjaga kualitas ikan kerapu yang dibudidayakan dengan KJA di Kecamatan Tanggetada, antara lain : penentuan waktu panen, teknik panen, serta penanganan pasca panen.

1. Waktu

Waktu panen di lokasi budidaya yang ada di Kecamatan Tanggetada dilakukan sekali dalam setahun antara bulan Desember sampai Februari dimana pada bulan ini harga ikan kerapu sunu cenderung meningkat dibandingkan bulan lain dengan ukuran masa panen berukuran 0,6 - $1 \mathrm{~kg}$ dan 
merupakan ukuran yang mempunyai nilai jual tinggi dan panen dilakukan pada pagi atau sore hari sehingga dapat mengurangi stress ikan pada saat panen.

2. Teknik Pemanenan

Teknik pemanenan yang dilakukan nelayan budidaya kerapu sunu dengan sistem KJA di lokasi budidaya yaitu dengan teknik panen total karena permintaan pasar yang sangat besar atau ukuran ikan seluruhnya sudah memenuhi kriteria jual.

Alat panen yang digunakan adalah scoop net yang terbuat dari kain kasa. Scoop net yang kasar tidak dianjurkan karena dapat menimbulkan luka yang dapat menyebabkan penyakit dan stres pada ikan saat dibawa ketempat penjualan atau konsumsi. Pemanenan ikan dapat dilakukan dengan cara mengangkat jaring pemeliharaan dengan tongkat kayu. Tongkat kayu diangkat sehingga jaring terbagi menjadi dua bagian sehinga dapat memudahkan pengambilan ikan dari jaring secara selektif maupun total.

3. Pasca Panen

Penanganan pasca panen yang utama adalah masalah pengangkutan sampai di tempat tujuan. Hal ini dimaksudkan untuk menjaga agar kesegaran ikan tetap dalam kondisi baik. Ini dilakukan dengan dua cara yaitu pengangkutan terbuka dan pengangkutan tertutup. Pengangkutan terbuka digunakan untuk jarak angkut dekat atau dengan jalan darat yang waktu angkutnya maksimal hanya 7 jam. Wadah angkutnya berupa drum plastik atau fiberglass yang sudah diisi air laut sebanyak $1 / 2$ sampai $2 / 3$ bagian wadah sesuai jumlah ikan. Suhu laut diusahakan tetap konstan selama perjalanan yaitu $19-21{ }^{\circ} \mathrm{C}$. Selama pengangkutan air perlu diberi aerasi.

\section{Aspek Managerial}

Pengelola kegiatan usaha budidaya kerapu sunu di lokasi usaha budidaya terdiri atas ketua dan anggota. Dimana ketua merangkap sebagai pemilik atau pelaksana usaha, pemilik modal dan pengelola keuangan dalam mengusahakan budidaya kerapu sunu yang ada di lokasi. Sedangkan tenaga kerja yang berjumlah 2 sampai 3 orang sebagai anggota. Tenaga kerja dalam usaha budidaya kerapu adalah tenaga kerja produktif yang dimana dalam melaksanakan atau melakukan kegiatan usaha tersebut adalah anggota keluarga sendiri.

\section{Aspek Pasar}

1. Potensi Permintaan dan Penawaran Pasar Permintaan ikan kerapu Hongkong juga berkaitan dengan siklus ekonomi dan budaya masyarakat Hongkong. Permintaan ikan kerapu cenderung naik menjelang tahun baru Imlek (tahun baru China) yang jatuh antara bulan Desember sampai Februari. Permintaan terendah akan terjadi pada saat hari raya Ching Bing yang jatuh pada bulan Juni (mengunjungi makam para leluhur) sebab saat itu masyarakat Hongkong sangat dipantangkan memakan ikan selama 4 hari berturut-turut.

2. Strategi Pemasaran

Dalam memasarkan hasil budidaya kerapu yang ada di lokasi budidaya belum memerlukan strategi promosi khusus, karena sampai saat ini pembudidaya dalam memasarkan hasil budidayanya belum merasa kesulitan, ini dikarenakan pembeli atau pedagang pengumpul (H. Said) yang berasal dari Makassar sudah siap menampung hasil panen pembudidaya.

3. Harga

Harga ikan kerapu sunu yang diterima oleh pembudidaya di lokasi usaha budidaya Kecamatan Tanggetada dengan kesepakatan harga dari tengkulak berkisar 
antara Rp. 450.000,- sampai Rp. 600.000,$/ \mathrm{kg}$ dengan ukuran $0,6-1 \mathrm{~kg}$, sedangkan di Jakarta berkisar antara Rp 750.000 hingga Rp. $1.000 .000 / \mathrm{kg}$ ini dikarenakan harga ikan cenderung naik pada saat mendekati hari besar Cina (Imlek).

4. Perkiraan Penjualan

Perkiraan penjualan ikan kerapu sunu yang bisa dicapai dari hasil budidaya KJA di daerah penelitian sebanyak 1,3 ton/musim tanam, perkiraan penjualan disesuaikan dengan kemampuan produksi. Rata-rata produksi ikan kerapu tiap pembudidaya $\pm 85,33 \mathrm{~kg}$.

5. Struktur Pasar
Struktur pasar yang ada di lokasi usaha budidaya kerapu sunu yaitu dimana banyak penjual beberapa pembeli hasil budidaya kerapu sunu berasal dari Makassar sehingga nelayan pembudidaya tidak merasa kesulitan untuk menjual hasil produksinya.

6. Persaingan Usaha

Persaingan usaha yang ada di lokasi budidaya perlu diperhatikan karena dengan banyaknya usaha yang membudidayakan ikan kerapu sunu jelas terjadi juga persaingan harga, kualitas, dan mutu. Namun persaingan usaha tersebut tidak ada masalah karena pasar mampu menyerap komoditas ikan kerapu sunu.

\section{Aspek Finansial}

\section{Biaya Produksi}

Tabel 1. Penggunaan Biaya Tetap pada Usaha Budidaya Kerapu Sunu di Kecamatan Tanggetada, Tahun 2016

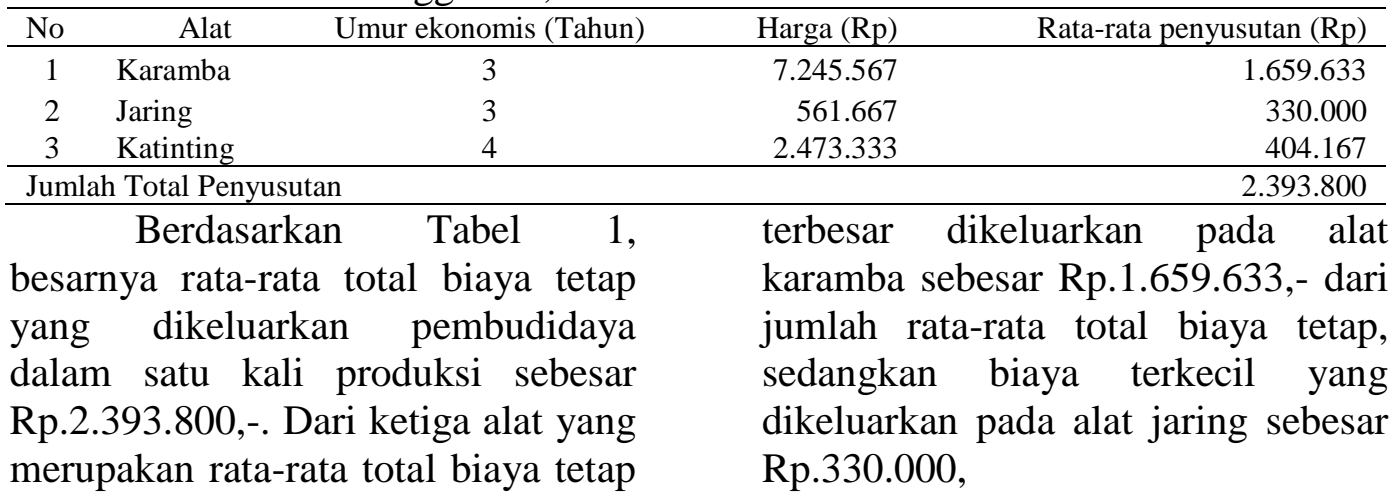

Tabel 2. Penggunaan Biaya Variabel pada Usaha Budidaya Kerapu Sunu di Kecamatan Tanggetada, Tahun 2016

\begin{tabular}{cllr}
\hline No. & Penggunaan & & Rata-rata (Rp/Produksi) \\
\hline 1 & Bibit & & 2.600 .000 \\
2 & Pakan & & 5.080 .000 \\
3 & Tenaga Kerja & & 3.430 .000 \\
\hline Jumlah & & 11.110 .000 \\
\hline & Rata-rata biaya variabel yang & Rp.5.080.000,- dari rata-rata total \\
dikeluarkan pada usaha budidaya & biaya variabel dan yang terkecil \\
kerapu sunu sebesar Rp.11.110.000,- & dikeluarkan pembudidaya yaitu \\
. Rata-rata biaya variabel terbesar & untuk pembelian bibit sebesar \\
yang dikeluarkan pembudidaya & Rp.2.600.000,-. \\
adalah pembelian pakan sebesar &
\end{tabular}


Tabel 3. Biaya Usaha Budidaya Kerapu Sunu di Kecamatan Tanggetada, Tahun 2016

\begin{tabular}{clrr}
\hline No. & Uraian (Rata-rata) & & Jumlah (Rp) \\
\hline 1 & Biaya tetap & & 2.393 .800 \\
2 & Biaya variabel & & 11.110 .000 \\
\hline Total biaya & & 13.503 .800 \\
\hline Rata-rata total biaya yang & kerapu sunu dalam satu kali produksi \\
dikeluarkan pada usaha budidaya & adalah sebesar Rp. 13.503.800,-
\end{tabular}

\section{Penerimaan dan Pendapatan}

Tabel 4. Penerimaan dan Pendapatan Usaha Budidaya Kerapu sunu di Kecamatan Tanggetada, Tahun 2016

\begin{tabular}{clr}
\hline No & Uraian & Rata-rata nilai \\
\hline 1 & Jumlah produksi (Kg) & 85,33 \\
2 & Harga (Rp) & 600.000 \\
3 & Penerimaan (Rp) & 51.200 .000 \\
4 & Pendapatan (Rp) & 37.696 .200 \\
\hline
\end{tabular}

Dari Tabel 4, diketahui harga jual ikan yang ada di lokasi budidaya kerapu sebesar Rp. $600.000 / \mathrm{kg}$ dengan jumlah produksi rata-rata $85,33 \mathrm{~kg}$. Dengan demikian rata-rata total penerimaan usaha budidaya kerapu sunu adalah sebesar Rp. 51.200.000,- tiap satu kali produksi dengan rata-rata pendapatan sebesar Rp 37.696.200,-. Diperkirakan oleh pembudidaya dan biasanya pada bulan Desember sampai dengan Februari atau menjelang hari raya Cina (imlek), nilai jual ekspor ikan kerapu sunu cenderung meningkat berkisar antara Rp.1.000.000 hingga $1.350 .000 / \mathrm{kg}$ dengan berat rata-rata $0,7-1,2 \mathrm{~kg}$ dan panjang total $\pm 30 \mathrm{~cm}$ dengan ukuran $1,2 \mathrm{~kg}$.

Untuk mengetahui kelayakan usaha budidaya ikan kerapu sunu dengan sistem KJA di Kecamatan Tanggetada dilakukan dengan menggunakan analisis Revenue Cost Ratio dengan persamaan sebagai berikut :

$$
R / C \text { Ratio }=\frac{51 \cdot 200 \cdot 000}{13 \cdot 503 \cdot 800}=3,79
$$

Berdasarkan hasil

perhitungan Revenue Cost Ratio diperoleh nilai sebesar 3,79. Nilai tersebut menunjukan bahwa pengembangan usaha budidaya ikan kerapu sunu di Kecamatan Tanggetada layak secara finansial, karena dalam penggunaan 1 rupiah input produksi menghasilkan penerimaan sebesar 3,79 rupiah.

Stretegi Pengembangan Usaha Budidaya Ikan Kerapu Sunu di Kecamatan Tanggetada

Strategi dan pengembangan usaha budidaya ikan kerapu dengan sistem KJA di Kecamatan Tanggetada dilakukan dengan menganalisis faktor-faktor strategis usaha budidaya kerapu melalui analisis SWOT yaitu menganalisis kekuatan (Strenghts), kelemahan (Weaknesses), peluang (Opportunity) dan ancaman (Threats).

Identifikasi Faktor Internal Pengambangan Usaha Budidaya Ikan Kerapu Sunu di Kecamatan Tanggetada 
Tabel 5. Faktor Identifikasi Strategi Internal Usaha Budidaya Kerapu Sunu di Kecamatan Tanggetada, Tahun 2016

\begin{tabular}{clccc}
\hline No. & \multicolumn{1}{c}{ Uraian } & Bobot & Rating & Rating x Bobot \\
\hline 1. & Kekuatan (Strength) & & & \\
a. & Letak lokasi budidaya & 0,20 & 4 & 0,80 \\
b. & Pemasaran & 0,10 & 3 & 0,30 \\
c. & Potensi SDM & 0,15 & 3 & 0,45
\end{tabular}

\begin{tabular}{clccc}
\hline 2. & Kelemahan (Weakness) & & & \\
a. & Manajemen yg kurang baik & 0,15 & 2 & 0,30 \\
b. Pengetahuan yg rendah & 0,15 & 2 & 0,30 \\
c. Keterbatasan modal & 0,05 & 3 & 0,15 \\
d. & Ketersediaan bibit & 0,20 & 2 & 0,40
\end{tabular}

\begin{tabular}{cccc}
\hline \multicolumn{2}{c}{ Jumlah } & 1,00 & 2,70 \\
\hline Berdasarkan & Tabel & 5, & Sedangkan faktor kelemahan yang
\end{tabular}
diketahui bahwa diantara faktor- paling tinggi adalah keterbatasan faktor strategi internal, faktor bibit dengan skor 0,40. Bibit yang kekuatan yang paling besar adalah terbatas membuat nelayan budidaya letak lokasi budidaya dengan skor di Kecamatan Tanggetada 0,80. Hal itu menunjukkan bahwa mengalami kesulitan untuk letak lokasi budidaya merupakan mengembangkan usahanya. faktor utama yang dapat memberi Kelemahan tersebut perlu diatasi pengaruh positif terhadap dengan bantuan dari pemerintah pengembangan usaha budidaya ikan untuk melakukan pembenihan agar kerapu sunu di Kecamatan pembudidaya lebih meningkatkan Tanggetada. Oleh karena itu, letak lokasi budidaya ikan kerapu sunu di Kecamatan Tanggetada perlu dipertahankan dan ditingkatkan agar tetap menjadi kekuatan bagi nelayan budidaya di Kecamatan Tanggetada. produksinya.

Identifikasi Faktor Eksternal Pengambangan Usaha Budidaya Ikan Kerapu Sunu di Kecamatan Tanggetada

Tabel 6. Faktor Identifikasi Strategi Eksternal Usaha Budidaya Kerapu Sunu di Kecamatan Tanggetada, Tahun 2016

\begin{tabular}{clccc}
\hline No. & \multicolumn{1}{c}{ Uraian } & Bobot & Rating & Rating x Bobot \\
\hline 1. & Peluang (Opportunity) & & & \\
a. & Harga & 0,15 & 4 & 0,60 \\
b. & Dukungan pemerintah & 0,20 & 4 & 0,80 \\
c. & Pasar & 0,10 & 3 & 0,30 \\
d. & Kemajuan teknologi & 0,15 & 3 & 0,45
\end{tabular}

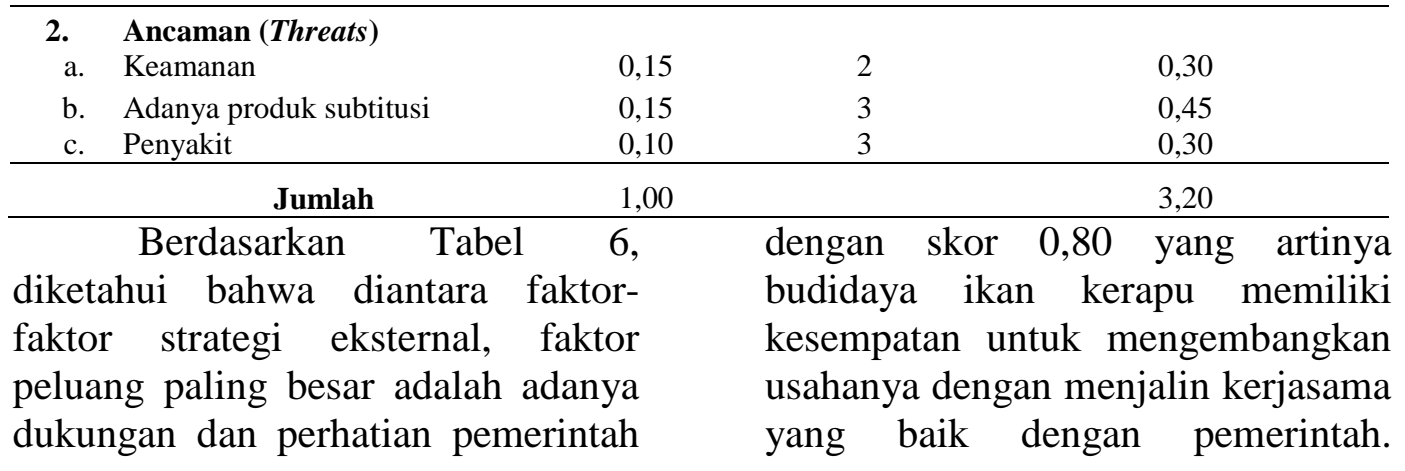


Bentuk kerjasamanya dapat berupa pelatihan, bantuan modal, maupun publikasi dan promosi. Faktor ancaman yang paling tinggi adalah adanya produk subtitusi dengan skor 0,45 . Hal ini menunjukkan bahwa jika tidak dikelola dengan baik dan benar secara berkelanjutan, maka akan berkambangnya jenis ikan lain yang dapat menggantikan jenis ikan kerapu sunu yang ada dilokasi budidaya. Oleh karena itu, usaha budidaya ikan kerapu sunu di Kecamatan Tanggetada perlu meningkatkan kualitas dan kuantitas produk untuk menjamin keberlanjutan dari usaha budidaya kerapu sunu di Kecamatan Tanggetada. Skor total faktor strategi eksternal sebesar 3,20 lebih besar dari skor total faktor strategi internal sebesar 2,70. Nilai tersebut menunjukkan bahwa faktor-faktor strategi eksternal lebih berpengaruh terhadap pengembangan usaha budidaya ikan kerapu sunu di Kecamatan Tanggetada dibanding dengan faktor-faktor strategi internalnya.

Berdasarkan analisis internal dan eksternal yang dilakukan, maka unsur-unsur yang termasuk dalam kekuatan, kelemahan, peluang dan ancaman yang harus diantisipasi dalam menghadapi persaingan di masa sekarang dan di masa yang akan datang adalah sebagai berikut :

\section{Kekuatan}

a. Letak lokasi budidaya, sangat mendukung untuk pengembangan usaha budidaya ikan kerapu sunu karena memenuhi persyaratan seperti perairan yang terlindung dari angin, gelombang besar, letak lokasi yang tidak menggangu jalur kapal, dasar perairan merupakan habitat alami ikan kerapu, sarana tranportasi yang tersedia, relatif dengan sumber pakan alami, dan bebas dari bahan pencemar seperti limbah rumah tangga dan jauh dari lokasi pertambangan.

b. Pemasaran, dalam melakukan pemasaran hasil budidaya ikan kerapu dilokasi cukup lancar karena semua produksi dapat diserap oleh pasar, pembeli atau tengkulak dari Makassar datang sendiri ketempat usaha budidaya bahkan sering kali ikan dipesan sebelum saatnya panen dan pembayaran dilakukan secara tunai.

c. Potensi SDM, adanya jaminan ketersediaannya tenaga kerja yang produktif dimana yang dimaksud tenaga kerja produktif adalah jumlah anggota keluarga rata-rata pembudidaya sebanyak 2-3 orang dan merupakan kontribusi yang cukup besar terhadap kegiatan usaha budidaya kerapu dengan sistem KJA.

\section{Kelemahan}

a. Manajemen yang kurang baik, salah satu bentuk manajemen yang kurang baik yang dilakukan oleh pembudidaya adalah dalam mengelola keuangan, yang dimaksud dalam hal ini adalah nilai uang atau barang hasil penerimaan yang disisakan pembudidaya untuk keperluan pembiayaan perbaikan atau penambahan kotak/jaring serta pembudidaya belum memiliki laporan keuangan yang dapat menggambarkan apakah usaha tersebut mengalami peningkatan 
atau penurunan tiap satu kali produksi.

b. Pengetahuan yang rendah, dari hasil penelitian di lokasi budidaya rata-rata pembudidaya yang ada di Kecamatan Tanggetada hanya berdasarkan pengalaman atau masih bersifat tradisional dalam melaksanakan kegiatan usaha budidaya ikan kerapu dengan sistem KJA. Hal ini juga dapat mempengaruhi produktifitas usaha budidaya yang dijalankan oleh pembudidaya.

c. Keterbatasan modal, dalam hal ini keadaan modal yang membatasi tiap pembudidaya juga sangat mempengaruhi untuk mengembangkan usaha budidaya kerapu sunu dengan sistem KJA sehingga perlunya peran pemerintah dalam mendukung keberlanjutan usaha budidaya ini.

d. Ketersediaan bibit, tidak terjamin dipasar karena pengadaan bibit pada sektor usaha ini belum ada sehingga pembudidaya hanya mengandalkan bibit dari alam atau tangkapan nelayan dengan menggunakan alat tangkap bubu.

\section{Peluang}

a. Harga, harga jual yang cenderung naik akan memberikan peluang pembudidaya kerapu sunu di Kecamatan Tanggetada untuk memperoleh keuntungan yang lebih tinggi.

b. Dukungan pemerintah daerah, kebijakan-kebijakan pemerintah dalam mendukung pengembangan usaha dan mampu menjadi fasilitator serta mampu memberikan bantuan modal dan memfasilitasi pembudidaya c. Pasar, permintaan akan ikan kerapu sunu dari negara-negara yang banyak etnis Chinese seperti China, Hongkong, Taiwan, Singapura dan Jepang dalam mengkonsumsi ikan hidup dan segar terus mengalami peningkatan, hal ini memberikan peluang bagi pembudidaya di Kecamatan Tanggetada untuk mengembangkan usaha budidayanya.

d. Kemajuan teknologi, kemajuan teknologi atau sistem informasi terhadap pembudidaya usaha budidaya kerapu dapat memberikan data yang cermat, tepat waktu, tepat isi dan penting bagi perencanaan dalam usaha budidaya kerapu.

4. Ancaman

a. Keamanan, keamanan yang belum baik yang dimaksud dilokasi budidaya kerapu yaitu adanya pencurian ikan yang sering terjadi pada malam hari menjadi ancaman tiap pembudidaya dalam menjalankan usahanya.

b. Adanya produk subtitusi, adanya pembudidaya yang membudidayakan jenis ikan lain selain ikan kerapu sunu. Hal ini menjadi ancaman bagi keberlanjutan usaha budidaya kerapu sunu dengan sistem KJA.

c. Penyakit, pengetahuan pengendalian hama dan penyakit masih rendah karena kurangnya informasi tentang pencegahan dan penaggulangan penyakit. 


\section{Pemilihan Alternatif Strategi \\ Pengembangan Usaha Budidaya \\ Kerapu Sunu di Kecamatan \\ Tanggetada}

Tabel 7. Matriks Faktor Internal dan Faktor Eksternal Pengembangan Usaha Budidaya Kerapu Sunu di Kecamatan Tanggetada, Tahun 2016

\begin{tabular}{|c|c|c|}
\hline Eksternal & $\begin{array}{c}\text { Peluang } \\
\text { (Opportunty = O) }\end{array}$ & $\begin{array}{c}\text { Ancaman } \\
(\text { Threats }=\mathrm{T})\end{array}$ \\
\hline Internal & $\begin{array}{ll}\text { a. } & \text { Harga } \\
\text { b. Dukungan pemerintah } \\
\text { c. Pasar } \\
\text { d. Kemajuan teknologi }\end{array}$ & $\begin{array}{ll}\text { a. Keamanan } & \\
\text { b. Adanya pr } & \\
\text { subtitusi } & \\
\text { c. } & \text { Penyakit }\end{array}$ \\
\hline $\begin{array}{c}\text { Kekuatan } \\
(\text { Strenght }=\mathrm{S})\end{array}$ & $\begin{array}{c}\text { Strategi } \\
(\mathrm{S}-\mathrm{O})\end{array}$ & $\begin{array}{c}\text { Strategi } \\
(\mathrm{S}-\mathrm{T})\end{array}$ \\
\hline $\begin{array}{ll}\text { a. } & \text { Letak lokasi budidaya } \\
\text { b. } & \text { Pemasaran } \\
\text { c. } & \text { Potensi SDM }\end{array}$ & 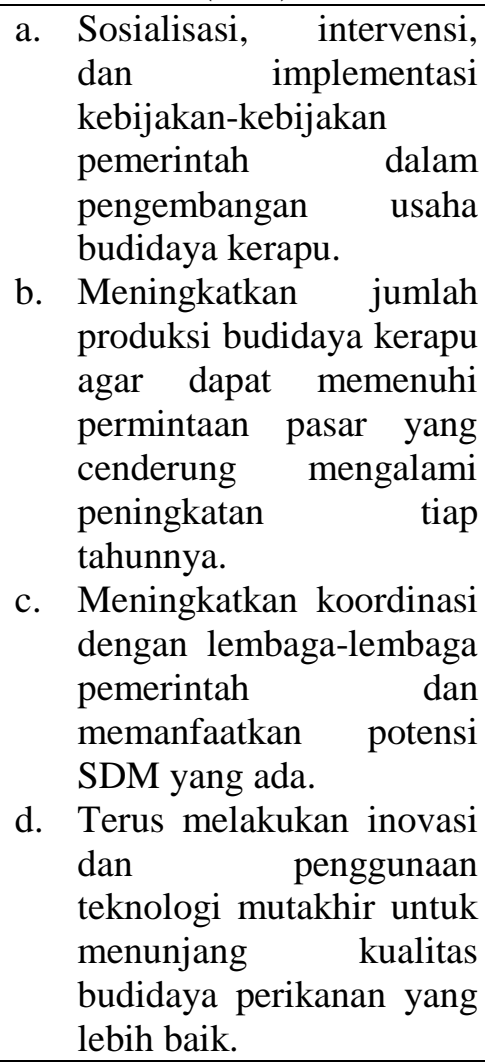 & 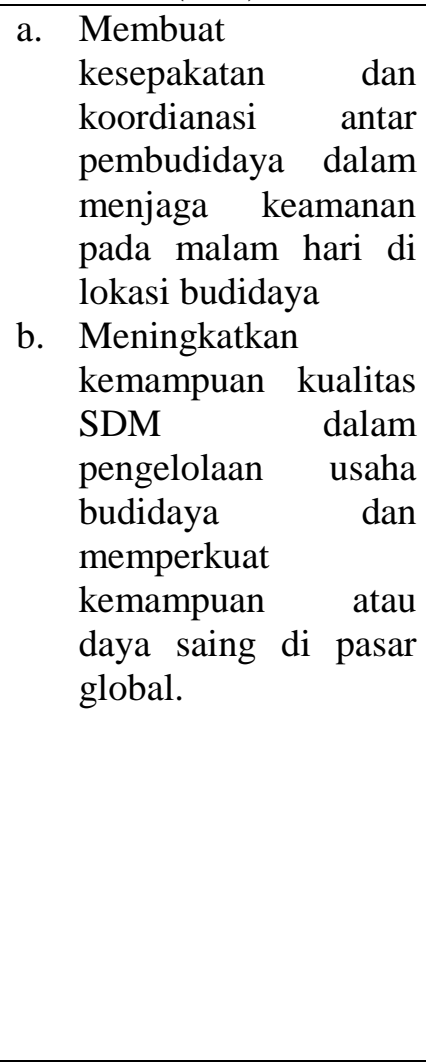 \\
\hline $\begin{array}{c}\text { Kelemahan } \\
(\text { Weakness = W) }\end{array}$ & $\begin{array}{c}\text { Strategi } \\
(\mathrm{W}-\mathrm{O})\end{array}$ & $\begin{array}{c}\text { Strategi } \\
(\mathrm{W}-\mathrm{T})\end{array}$ \\
\hline $\begin{array}{l}\text { a. Manajemen yg kurang } \\
\text { baik } \\
\text { b. Pengetahuan yg rendah } \\
\text { c. Keterbatasan modal } \\
\text { d. Ketersediaan bibit }\end{array}$ & $\begin{array}{llr}\text { a. Perlu diciptakan suatu } & \begin{array}{l}\text { untuk } \\
\text { strategi }\end{array} \\
\text { mengantisipasi biaya } \\
\text { budidaya yang tinggi } \\
\text { dengan membuat } \\
\text { terobosan-terobosan baru } \\
\text { dalam menekan biaya } \\
\text { operasional. } \\
\text { b. Melakukan koordinasi }\end{array}$ & 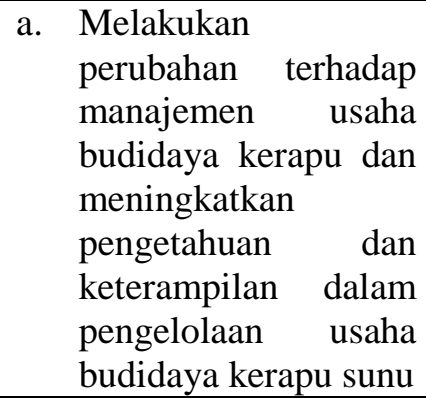 \\
\hline
\end{tabular}




\begin{tabular}{|c|c|c|}
\hline & $\begin{array}{l}\text { dengan pemerintah atau } \\
\text { instansi terkait dalam } \\
\text { meningkatkan } \\
\text { pengetahuan tentang } \\
\text { manajemen usaha dan } \\
\text { pemanfaatan teknologi } \\
\text { serta inovasi dalam } \\
\text { usaha budidaya kerapu } \\
\text { c. Kepedulian pihak } \\
\text { perbankan } \\
\text { menunjang dalam } \\
\text { pengembangan usaha } \\
\text { budidaya kerapu dengan } \\
\text { sistem KJA. } \\
\text { d. Peran pemerintah dalam } \\
\text { mendukung } \\
\text { pengembangan usaha } \\
\text { budidaya kerapu sunu } \\
\text { dengan mengupayakan } \\
\text { bibit atau benih yang } \\
\text { memadai. }\end{array}$ & 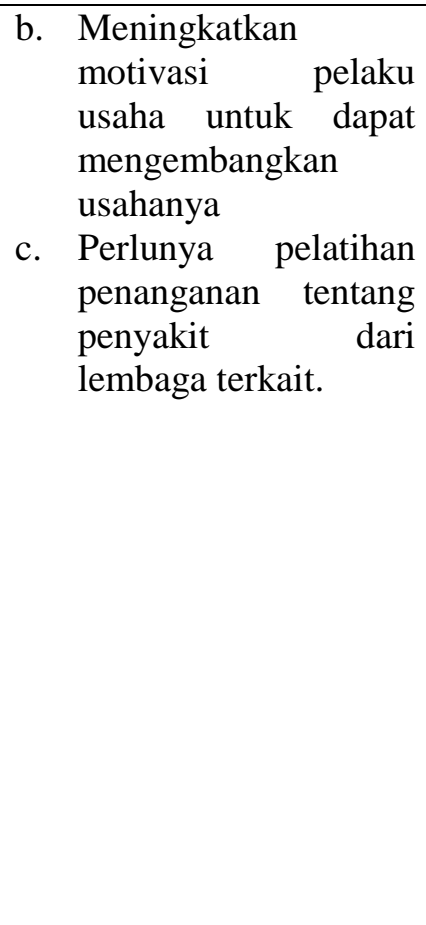 \\
\hline $\begin{array}{l}\text { Berdasarkan rumusar } \\
\text { usaha budidaya kerapu sun } \\
\text { sistem KJA didapatkan } \\
\text { alternatif strategi yang melip } \\
\text { a. Meningkatkan kapasitas } \\
\text { ikan kerapu sunu } \\
\text { pembesaran dan penge } \\
\text { usaha-usaha budidaya } \\
\text { kerapu dengan sister } \\
\text { berskala kecil dan m } \\
\text { dengan pola kemitraan } \\
\text { b. Meningkatkan ken } \\
\text { penguasaan teknolog } \\
\text { manajeman budidaya un } \\
\text { pembudidaya sebagai } \\
\text { usaha budidaya ikan ker } \\
\text { melalui pelatihan ( } w \\
\text { oleh dinas perikana } \\
\text { kelautan serta dinas } \\
\text { terkait lainnya. } \\
\text { Meningkatkan koordinas } \\
\text { semua lembaga terkait } \\
\text { lembaga permodalan } \\
\text { membuat kebijakan-k } \\
\text { dan regulasi yang mer } \\
\text { pembesaran dan penger } \\
\text { usaha budidaya ikan }\end{array}$ & 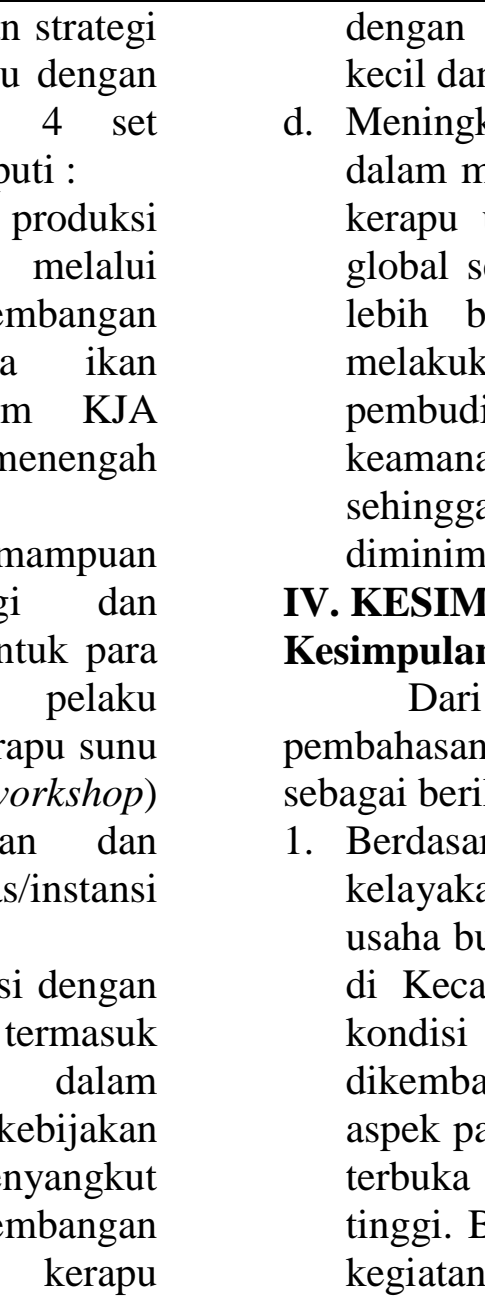 & 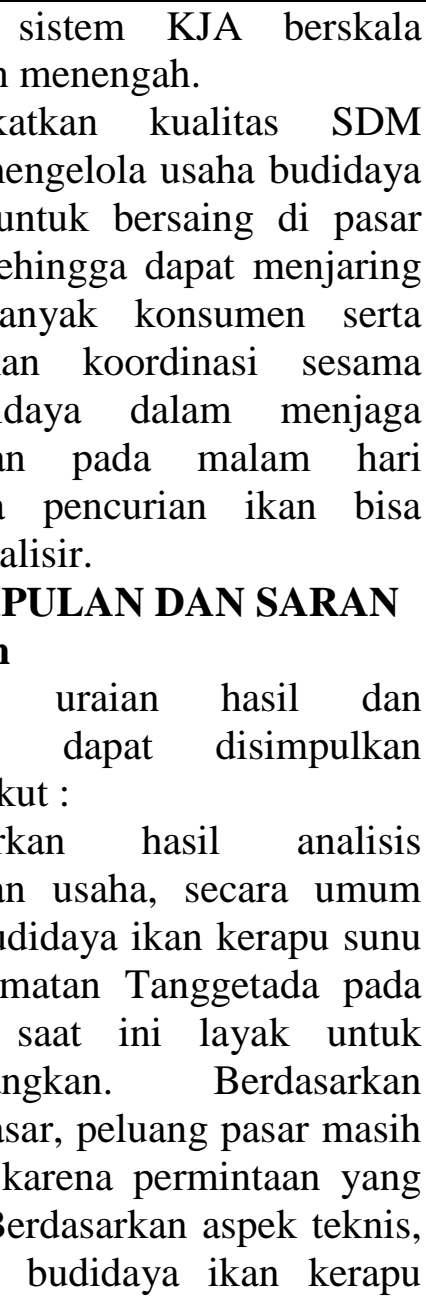 \\
\hline
\end{tabular}


sunu menggunakan teknologi dan peralatan relatif sederhana seperti budidaya perikanan pada umumnya. Berdasarkan aspek manajemen, budidaya ikan kerapu sunu dapat dilakukan secara perseorangan dan tidak memerlukan organisasi yang kompleks.

2. Dari hasil Revenue Cost Ratio diperoleh nilai sebesar 3,79. Nilai tersebut menunjukan bahwa pengembangan usaha budidaya ikan kerapu sunu di Kecamatan Tanggetada layak secara finansial, karena dalam penggunaan 1 rupiah input produksi menghasilkan penerimaan sebesar 3,79 rupiah.

3. Berdasarkan rumusan strategi usaha budidaya kerapu sunu dengan sistem KJA didapatkan 4 set alternatif strategi yang meliputi :

a. Meningkatkan kapasitas produksi ikan kerapu sunu melalui pembesaran dan pengembangan usaha-usaha budidaya ikan kerapu dengan sistem KJA berskala kecil dan menengah dengan pola kemitraan

b. Meningkatkan kemampuan penguasaan teknologi dan manajeman budidaya untuk para pembudidaya sebagai pelaku usaha budidaya ikan kerapu sunu melalui pelatihan (workshop) oleh dinas perikanan dan kelautan serta dinas/instansi terkait lainnya.

c. Meningkatkan koordinasi dengan semua lembaga terkait termasuk lembaga permodalan dalam membuat kebijakan-kebijakan dan regulasi yang menyangkut pembesaran dan pengembangan usaha budidaya ikan kerapu dengan sistem KJA berskala kecil dan menengah.

d. Meningkatkan kualitas SDM dalam mengelola usaha budidaya kerapu untuk bersaing di pasar global sehingga dapat menjaring lebih banyak konsumen serta melakukan koordinasi sesama pembudidaya dalam 'menjaga keamanan pada malam hari sehingga pencurian ikan bisa diminimalisir.

\section{Saran}

1. Perlu adanya pembentukan kelompok nelayan tangkap bibit ikan kerapu sunu di Kecamatan Tanggetada untuk menyuplai bibit ikan kerapu sunu agar nelayan budidaya tidak lagi merasa kesulitan mencari bibit.

2. Bagi masyarakat yang tertarik pada usaha pengusahaan ikan kerapu sunu, jangan takut untuk menjalankan usaha ini karena pengusahaan ikan kerapu sunu ini terbukti menguntungkan meskipun dilaksanakan dalam skala usaha kecil.

3. Pemerintah sebaiknya memberikan sosialisasi dan edukasi kepada masyarakat mengenai pengusahaan ikan kerapu sunu agar semakin banyak masyarakat yang mengetahui pengusahaan ikan kerapu sunu dan tertarik untuk mengusahakannya.

\section{DAFTAR PUSTAKA}

DKP. 2012. Laporan Perikanan Tahunan Kabupaten 
Kolaka 2011. Dinas

Kelautan dan Perikanan

Kabupaten Kolaka.

Kolaka.

La Sara. 2005. Kondisi Pembangunan Sektor Kelautan dan Perikanan di Sulawesi Tenggara. Potensi, Isu, dan Upaya Pemberdayaan Nelayan dan Pembudidaya Ikan. Disampaikan

Pada
Seminar Nasional

Dalam Lokakarya

Regional. Dalam

Rangka HUT XXXIX

Provinsi Sulawesi

Tenggara, Tanggal 25-

28 April 2005, Kendari.

Rangkuti, F. 2003. Analisis SWOT

Teknik Membedah

Kasus Bisnis. PT.

Gramedia Pustaka

Utama. Jakarta. 